\title{
SANKSI PIDANA BAGI PEGAWAI NEGERI SIPIL (PNS) YANG TIDAK NETRAL DALAM PEMILIHAN KEPALA DAERAH (PILKADA) KOTA BAUBAU BERDASARKAN UNDANG-UNDANG APARATUR SIPIL NEGARA
}

\author{
Oleh \\ La Ode Dedi Abdullah \\ Dosen Fakultas Hukum \\ Universitas Muhammadiyah Buton
}

\begin{abstract}
This research aims to know the criminal sanctions for civil servants (CIVIL SERVANTS) who are not neutral in the election of the head of the area (of the elections) town of Baubau on the basis of legislation ASN. The method used is the normative research methods, the data obtained will be analyzed are descriptive. Results found is the Neutrality of CIVIL SERVANTS, is the solution to solve the problems of the participation of CIVIL SERVANTS in political parties. With the inception of law No. 2014 about 15 years of Civilian rule, State Apparatus is expected to neutralize Government and then the Government should be able to realize the regulation, thus the goal of neutrality would be achieved. Law enforcement against the neutrality of CIVIL SERVANTS, in its realization have difficulties, because the arrangements regarding law enforcement civil service neutrality which is regulated in Act No. 43 of 1999 Staffing issues, namely article 3 and The common explanation I number 6, giving sanctions for CIVIL SERVANTS who violate this regulation be removed from civil servants, these regulations only set up for CIVIL SERVANTS and members of the Executive Board of the Centre, so that the regulation has not been able to resolve any violations about neutrality.
\end{abstract}

Keywords: Criminal Sanctions, Civil Servant, Elections

\section{A. Latar Belakang}

Negara Indonesia adalah Negara hukum, sebagaimana yang tercantum dalam Pasal 1ayat (3) Undang-Undang Dasar Negara Republik Indonesia 1945.Salah satu ciri negara hukum yaitu adanya sistem demokrasi yang berkedaulatan rakyat. Penyelanggaraan sistem demokrasi Negara harus bertumpu pada partisipasi dan kepentingan rakyat. Salah satu ciri negara hukum yang demokratis adalah penyelenggaraan pemilihan umum untuk memilih pemimpin secara langsung.Pemilihan umum ada 2,yaitu pemilihan umum Presiden dan Wakil Presiden serta pemilihan umum LegislatifKepala Daerah.Tulisan ini yang akanmembahas lebih rinci ialah tentang pemilihanKepala Daerah.

Pada pasal 18 ayat (4) Undang-Undang Dasar Negara Republik Indonesia PemilihanKepala Daerahdan Wakil Kepala Daerah, atauseringkalidisebut Pilkada, adalah pemilihan untuk memilih Kepala Daerah dan Wakil Kepala Daerah secara langsung di 
Indonesia oleh penduduk daerah setempat yang memenuhi syarat. Sebelumnya, Kepala Daerah dan Wakil Kepala Daerah dipilih oleh Dewan Perwakilan Rakyat Daerah (DPRD).

Daerah dan Wakil Kepala Daerah Langsung atau sering disebut Pilkada Langsung merupakan mekanisme demokratis dalam rangka rekrutmen pemimpin di daerah, dimana rakyat secara menyeluruh memiliki hak dan kebebasan untuk memilih calon-calon yang didukungnya. Indonesia sendiri baru memberlakukan Pilkada secara langsung ketika dikeluarkannya Undang-Undang Nomor 32 Tahun 2004 tentang Pemerintahan Daerah dan Peraturan Pemerintah Nomor 6 Tahun 2005 mengenai Tata Cara Pemilihan, Pengesahan, Pengangkatan, dan Pemberhentian Kepala Daerah, merupakan tonggak baru penegakan kedaulatan rakyat daerah di Indonesia. Undang-Undang Nomor 32 Tahun 2004 ditetapkan pada Oktober 2004 memberikan perubahan yang sangat sigifikan dalam tata pemerintahan dan bahkan adanya pemilihan Kepala Daerah secara langsung. Ini berarti semangat untuk memberikan kesempatan seluas-luasnya bagi masyarakat daerah untuk berbenah sesuai dengan keinginannya. Pada akhirnya setiap Kepala Daerah akan terasa lebih dekat dengan rakyat. Artinya semua kebijakan yang akan diambil Kepala Daerah benar-benar berdasarkan kebutuhan rakyat yang sesungguhnya.

Perhelatan ini tentu membutuhkan beragam dukungan dan bantuan dari semua pihak. Seluruh lapisan anak bangsa hendaknya memberikan sumbangsihnya bagi berhasilnya pilkada serentak ini. Namun, dukungan dan bantuan tersebut hendaknya dalam porsinya masing-masing dan tidak keluar dari norma dan aturan-aturan yang berlaku. Dukungan ini juga berasal dari para Aparatur Sipi Negara (ASN), namun dukungan ini tidak boleh keluar dari prinsip netralitas yang harus dipegang oleh stiap individu ASN. Prinsip netralitas ini perlu dijaga agar profesionalitas dan pelayanan public yang merupakan tugas utama mereka, tetap dapat dilaksanakan dengan maksimal. Netralitas birokrat ini diatur dalam Peraturan Pemerintah (PP) Nomor 53 Tahun 2010 tentang disiplin PNS, bahwa kepala daerah bertanggung jawab menegakkan sanksi kepada PNS yang terlibat pelanggaran dalam pilkada, baik dalam hal netralitas maupun pemanfaatan fasilitas Negara. Karena kepala daerah adalah PPK (pejabat Pembina kepegawaian). Institusi birokrasi dan individu birokrat harus dijaga ketidakberpihakannya kepada salah 
satu peserta pilkada, semua kandidat harus diperlakukan sama, tanpa perbedaan baik dalam hal keterlibatan langsung, maupun tidak langsung.

Ketidak berpihakan ini juga berlaku untuk pemberian fasilitas Negara untuk mereka gunakan, terutama jika kandidatnya adalah petahana. UU No. 5 Tahun 2014 tentang ASN juga mengatur hal ini, bahwa dalam upaya menjaga netralitas ASN dari pengaruh 8 partai politik dan untuk menjamin keutuhan, kekompakan, dan persatuan ASN, serta dapat memusatkan segala perhatian, pikiran, dan tenaga pada tugas yang dibebankan, ASN dilarang menjadi anggota dan/atau pengurus partai politik.

Netralitas merupakan salah satu azas penyelenggaraan kebijakan dan Manajemen ASN dalam UU No 5 Tahun 2014 tentang Aparatur Sipil Negara. Yang dimaksud dengan "asas netralitas" adalah bahwa setiap Pegawai ASN tidak berpihak dari segala bentuk pengaruh manapun dan tidak memihak kepada kepentingan siapapun. Tulisan ini bertujuan untuk mengkaji tentang "Sanksi Pidana Bagi Pegawai Negeri Sipil (PNS) yang tidak Netral Dalam Pemilihan Kepala Daerah (Pilkada) Kota Baubau Berdasarkan UndangUndang ASN".

Berdasarkan uraian latar belakang masalah diatas maka yang menjadi fokus identifikasi permasalahan dalam penulisan karya tulis ini adalah mengarah pada kajian hukum tentang netralitas PNS dilahat dari landasan yuridisnya tentang undang-undang ASN. Adapun rumusan masalah yang akan hendak di teliti adalaha bagaimana sanksi pidana bagi Pegawai Negeri Sipil (PNS) yang tidak netral dalam Pemilihan Kepala Daerah (Pilkada) Kota Baubau Berdasarkan Undang-Undang ASN?

\section{B. Metode Penelitian}

Metodologi merupakan cara kerja bagaimana menemukan atau memperoleh sesuatu atau menjalankan sesuatu kegiatan untuk memperoleh hasil yang konkrit dan cara utama untuk mencapai tujuan. Dalam penelitian ini metode yang digunakan adalah metode penelitian normatif, data yang diperoleh akan dianalisa secara deskriptif. Penelitian ini mengarah pada kajian tentang netralitas PNS dilahat dari landasan yuridisnya berdasrkan undang-undang ASN. Sumber bahan karya tulis ini terdiri dari undang-undang, buku dan literatur lainnya yang relevan. Analisis data merupakan suatu metode atau cara untuk 
menemukan jawaban atas permasalahan yang dibahas. Proses menemukan jawaban atas permasalahan yang dibahas menurut Peter Mahmud Marzuki dilakukan dengan tahap sebagai berikut:

1. Mengidentifikasi fakta hukum dan mengelimir hal-hal yag tidak relevan untuk menetapkan isu hukum yang hendak dipecahkan;

2. Pengumpulan bahan-bahan hukum dan bahan-bahan non hukum yang dipandang mempunyai relevansi;

3. Melakukan telaah atas isu hukum yang diajukan berdasarkan bahan-bahan yang telah dikumpulkan;

4. Menarik kesimpulan dalam bentuk argumentasi yang menjawab isu hukum; dan

5. Memberikan persepsi berdasarkan argumentasi yang telah dibangun didalam kesimpulan

Hasil analisa bahan hukum sekunder tersebut diatas kemudian dibahas dengan metode deduktif untuk mendapatkan pemahaman atas permasalahan sehingga dapat ditarik suatu kesimpulan yang dapat dipertanggungjawabkan. Metode deduktif yang dimaksud adalahsuatu metode yang diunakan untuk mengambil kesimpulan dari pembahasan yang bersifat umum menjadi kesimpulan yang bersifat khusus sehingga jawaban atas permasalahan dalam Karya tulis dapat tercapai.

\section{Hasil Penelitian}

\section{Netralitas Pegawai Negeri Sipil (PNS)}

Selama ini, PNS menjadi perdebatan dalam kehidupan demokrasi di Indonesia. Peraturan Pemerintah No. 5 Tahun 1999 jo Peraturan Pemerintah No. 12 Tahun 1999 dan terakhir dengan Peraturan pemerintah No.37 tahun 2004 tentang Larangan PNS menjadi Anggota Partai Politik ini di-maksudkan untuk menjawab permasalahan yang selama ini terjadi. Peraturan tersebut dimaksudkan PNS netral dalam partai politik.

Peraturan ini pula diharapkan dapat memberi angin segar dalam kehidupan partai politik di Indonesia karena selama ini PNS digunakan guna mendukung salah satu partai politik saja. Adanya peraturan ini diharapkan kehidupan berpolitik di Indonesia akan lebih demokratis tanpa diwarnai rasa saling curiga. 
Keadaan Pegawai Negeri pada masa Orde Baru yaitu 11 Maret 1966 sampai dengan 21 Mei 1998, yang dijadikan alasan era reformasi untuk segera membenahi peraturan tentang keikut sertaan PNS dalam partai politik. Hal ini dimulai dari Pengunduran diri Soeharto sebagai Presiden tanggal 21 Mei 1998 merupakan tonggak baru dalam kehidupan pemerintahan di Indonesia. Bersamaan dengan itu, hembusan angin reformasi yang berkaitan dengan partai politik dijadikan agenda utama. Pada masa reformasi, hal yang berkaitan dengan PNS dalam partai politikpun menjadi hangat dibicarakan akhirnya timbullh kebijakan tentang netralitas PNS.

Akibat permainan politik yang dilakukan pada Orde Baru tentang pegawai negeri dalam partai politik mengakibatkan ketidakseimbangan dalam perolehan suara setiap pemilu. Bahkan ini merupakan sumber konflik dalam partai politik. Kabinet Reformasi Pemerintah Habibie berupaya akan melakukan reformasi di segala bidang, dalam rangka reformasi politik menuju kehidupan politik yang lebih demokratis.

Upaya tersebut guna menciptakan pemerintahan yang baik, berwibawa dan bersih, termasuk di dalamnya tentang kedudukan Pegawai Negeri Sipil dalam kehidupan partai politik sudah saat-nya ditinjau kembali. Keinginan reformasi Pegawai Negeri Sipil dalam partai politik ini disebabkan Adanya pegawai negeri yang dijadikan alat politik golkar tersebut, meng-akibatkan fungsi PNS/birokrasi itu akan terganggu. Sebab setiap birokrasi dalam pembentukan dan perwujudan kebijaksanaan publik adalah sebagai "implementing agency" yaitu menghantarkan kebijaksanana publik itu ke masyarakat.

Atas dasar dan kenyataan masa Orde Baru ini, seyogyanya PNS itu Netral. Penulis setuju bahwa PNS untuk saat ini harus netral. Netralitas PNS dalam partai politik memang untuk saat ini sangat diperlukan. Hal ini seperti dinyatakan oleh Mahfud bahwa: Salah satu persoalan besar bangsa ini dalam kehidupan bernegara adalah persoalan netralitas pegawai negeri karena secara teoritis sulit ditemukan landasan teoritis yang dapat memberikan alasan pembenar bagi dimungkinkannya pegawai negeri untuk terlibat dalam kegiatankegiatan politik praktis. Akibat penyelewengan yang dilakukan itu, tuntutan agar Pegawai Negeri Sipil netral dalam partai politik dalam keanggotaan dan kepengurusan dalam partai politik adalah wajar. Karena selama Orde Baru KORPRI dijadikan mesin 
politik Golkar. Sedangkan keanggotaan KORPRI sebagian besar adalah Pegawai Negeri Sipil.

Jadi netralitas pegawai negeri diperlukan sepanjang sifatnya hanya sementara dan selama masa transisi, bukan bersifat langgeng untuk jangka waktu yang panjang. Karena apabila berlangsung lama mengkibatkan hilangnya kebebasan berserikat bagi pegawai negeri sipil. Dengan demikian netralitas pegawa negeri diperlukan hanya untuk menyelesaikan konflik yang terjadi selama Orde Baru.

Netralitas PNS yang sudah berjalan selama 10 tahun, perlu direnungkan kembali, konsekensi terhadap kualitas, moralitas, pengalaman anggota dewan. Anggota dewan adalah wakil rakyat yang akan menjadikan negara ini kearah mana, sehingga diharapkan anggota dewan syarat dengan nama besar tersebut.

Netralitas diharapkan untuk perbaikan untuk masa mendatang. Dalam mengkaji netralitas, dibatasi dalam pengertian sebagaimana tertuang dalam Peraturan Pe-merintah No. 5 Tahun 1998 yang kemudian dirubah dengan Peraturan Pemerintah No. 12 Tahun 1998, yang sekarang diatur dalam Peraturan Pemerintah No. 37 Tahun 2004 tentang Larangan Pegawai Negeri Sipil yang menjadi anggota Partai Politik. Netralitas diatur pasal 3 adalah Dalam kedudukan sebagaimana dimaksud dalam pasal 2, pegawai negeri sipil harus bersikap netral dan menghindari fasilitas negara. Selanjutnya Netralitas ini juga dimaksudkan Pasal 4 adalah Pegawai negeri sipil dalam menyelenggarakan tugas pemerintah dan pembangunan sebagaimana dimaksud dalam pasal 2 tidak diskriminatif khususnya dalam memberikan pelayanan kepada masyarakat.

Menurut Marbun makna netralitas adalah Bebasnya Pegawai Negeri Sipil dari pengaruh kepentingan partai politik tertentu atau tidak memihak untuk kepentingan partai tertentu atau tidak berperan dalam proses politik. Namun Pegawai Negeri Sipil masih tetap mempunyai hak politik untuk memilih, dan berhak untuk dipilih dalma pemilihan umum.

Namun tidak diperkenankan aktif menjadi anggota dan pengurus partai Maksud netralitas yang lain adalah jika seorang Pegawai Negeri Sipil aktif menjadi pengurus partai politik atau anggota legislatif, maka ia harus mengundurkan diri. Dengan demikian 
birokrasi pemerintahan akan stabil dan dapat berperan mendukung serta merealisasikan kebijakan atau kehendak politik manapun yang sedang berkuasa dalam pemerintahan.

Makna netralitas tersebut di atas adalah bebasnya Pegawai Negeri Sipil dari pengaruh kepentingan partai politik tertentu atau tidak memihak untuk kepentingan partai tertentu atau tidak berperan dalam proses politik karena dikhawatirkan pegawai tersebut menyalahgunakan penggunaan fasilitas negara untuk kepentingan partai seperti yang telah terjadi pada masa Orde Baru. Jadi tidak ada larangan keterwakilan pegawai negeri dalam Lembaga perwakilan rakyat.

Netralitas, seyogyanya tidak dikaitkan dengan keterwakilan Pegawai negeri di dalam anggota Dewan. Sejarah membuktikan bahwa, pegawai negeri merupakan orang karier yang berpengalaman, bekerja tanpa imbalan yang menggiurkan sesuai dengan perannya, yang masih memikirkan kehormatan dirinya, untuk keluarga, masyarakat dan tugas-tugasnya, sehingga apabila pegawai negeri selesai menjalankan tugasnya sebagai dewan. Mereka masih berharap kembali menjadi seorang yang disegani dan dihormati, bahkan waktu berjalan juga menunjukkan jarang pegawai negeri terlibat skandal, korupsi ini menunjukan budaya malu masih sangat dijunjung tinggi Dengan demikian netralitas Pegawai negeri, adalah tidak melarang pegawai negeri duduk di anggota Dewan, yang bukan dari partai politik melalui perwakilan.

Data tersebut di atas juga didukung oleh data yang lain bahwa seseorang yang mendapat kesempatan belajar, seorang yang mempunyai karier untuk mengembangkan pengetahuannya, dan masih selalu memper-hatikan terhadap etika, rasa malu jika melakukan pelanggaran adalah Pegawai Negeri baik PNS, POLRI, maupun TNI, sehingga netralitas Pegawai negeri memang diperlukan. Jadi netralitas PNS tidak termasuk dalam larangan keterwakilan PNS dalam anggota Dewan. Apalagi menyimak kondisi anggota dewan yang akhir-akhir ini menjadi sorotan publik terhadap etika anggota dewan.

\section{Sanksi Pidana Bagi PNS yang Terlibat Politik Praktis}

Pelaksanaan penyelenggaraan pemilihan kepala daerah (Pilkada) serentak tahun 2018, pemilihan legislatif (Pileg) tahun 2019, dan pemilihan presiden dan wakil presiden (Pilpres) tahun 2019, semakin dekat. Menteri Pendayagunaan Aparatur Negara dan 
Reformasi Birokrasi (PANRB), Asman Abnur, pada 27 Desember 2017 telah mengirimkan surat kepada para pejabat Negara (mulai menteri Kabinet Kerja sampai Gubernur, Bupati/Wali Kota) mengenai pelaksanaan netralitas Aparatur Sipil Negara (ASN).

"Berdasarkan Pasal 2 huruf f Undang-Undang Nomor 5 Tahun 2014 tentang ASN, bahwa setiap pegawai ASN tidak berpihak dari segala pengaruh manapun dan tidak memihak kepada kepentingan siapapun," tulis Asman Abnur dalam suratnya, seperti dilansir hukumonline dari situs Setkab, Senin (2/1). Menteri PANRB mengingatkan, sesuai dengan putusan Mahkamah Konstitusi Nomor: 41/PUU-XIII/2014 tanggal 6 Juli 2015, PNS yang mencalonkan diri atau dicalonkan menjadi Gubernur/Wakil Gubernur, Bupati/Wakil Bupati, Wali kota/Wakil Wali kota wajib menyatakan pengunduran diri secara tertulis sebagai PNS sejak ditetapkan sebagai calon peserta Pemilihan Gubernur/Wakil Gubernur, Bupati/Wakil Bupati, Wali kota/Wakil Wali kota.

Mengutip Undang-Undang (UU) Nomor: 10 Tahun 2016, Menteri PANRB Asman Abnur juga menegaskan, pasangan calon dilarang melibatkan ASN anggota Polri dan anggota TNI, dan Kepala Desa atau perangkat Desa lainnya.

"Gubernur atau Wakil Gubernur, Bupati atau Wakil Bupati, Wali kota atau Wakil Wali kota dilarang melakukan pergantian pejabat 6 (enam) bulan sebelum tanggal penetapan pasangan calon sampai dengan akhir masa jabatan kecuali mendapat persetujuan tertulis dari Menteri," bunyi surat Menteri PANRB mengutip Pasal 71 Ayat (2) UU Nomor: 10 Tahun 2016.

Gubernur atau Wakil Gubernur, Bupati atau Wakil Bupati, Wali kota atau Wakil Wali kota, lanjut Menteri PANRB, dilarang menggunakan kewenangan program dan kegiatan yang menguntungkan atau merugikan salah satu pasangan calon, baik di daerah sendiri maupun di daerah lain 6 (enam) bulan sebelum tanggal penetapan pasangan calon sampai dengan penetapan pasangan calon terpilih. "Ketentuan sebagai dimaksud berlaku juga untuk Pejabat Gubernur atau Penjabat Bupati/Walikota," tegas Menteri PANRB dalam surat tersebut.

\section{Etika dan Netralitas PNS}


Etika dan Netralitas PNS dalamsurat tersebut, Menteri PANRB Asman Abnur juga mengutip ketentuan dalam Peraturan Pemerintah (PP) Nomor: 42 Tahun 2004 tentang Pembinaan Jiwa Korps dan Kode Etik Pegawai Negeri Sipil (PNS). "PNS dilarang melakukan perbuatan yang mengarah pada keberpihakan salah satu calon atau perbuatan yang mengindikasikan terlibat dalam politik praktis/berafiliasi dengan partai politik," Berikut contoh larangan dimaksud:

1. PNS dilarang melakukan pendekatan terhadap partai politik terkait rencana pengusulan dirinya atau orang lain sebagai bakal calon Kepala Daerah/Wakil Kepala Daerah;

2. PNS dilarang memasang spanduk/baliho yang mempromosikan dirinya atau orang lain sebagai bakal calon Kepala Daerah/Wakil Kepala Daerah;

3. PNS dilarang mendeklarasikan dirinya sebagai bakal calon Kepala Daerah/Wakil Kepala Daerah;

4. PNS dilarang menghadiri deklarasi bakal calon Kepala Daerah/Wakil Kepala Daerah dengan atau tanpa menggunakan atribut bakal pasangan calon/atribut partai politik;

5. PNS dilarang mengunggah, menanggapi atau menyebarluaskan gambar/foto bakal calon/bakal pasangan calon Kepala Daerah melalui media online maupun media sosial;

6. PNS dilarang melakukan foto bersama dengan bakal calon Kepala Daerah/Wakil Kepala Daerah dengan mengikuti simbol tangan/gerakan yang digunakan sebagai bentuk keberpihakan;

7. PNS dilarang menjadi pembicara/narasumber pada kegiatan pertemuan partai politik.

Untuk menjamin efektivitas pelaksanaan Surat Menteri PANRB ini, para pimpinan Kementerian/Lembaga dan Pemerintah Daerah agar melakukan pengawasan terhadap Aparatur Sipil Negara yang berada di lingkungan instansi masing-masing," bunyi akhir surat Menteri PANRB Asman Abnur, yang tembusannya disampaikan kepada Presiden dan Wakil Presiden.

Dalam suratnya itu, Menteri PANRB Asman Abnur juga menyampaikan beragam sanksi yang mengancam Aparatur Sipil Negara (ASN) termasuk Pegawai Negeri Sipil (PNS) 
jika tidak menjaga netralitas dalam penyelenggaraan Pemilihan Kepala Daerah (Pilkada), Pemilihan Anggota Legislatif (Pileg), dan Pemilihan Presiden dan Wakil Presiden (Pilpres). Berdasarkan Pasal 15 ayat (1) Peraturan Pemerintah (PP) Nomor: 42 Tahun 2004, terhadap pelanggaran berbagai jenis larangan kepada PNS dikenakan sanksi moral," tulis Menteri Asman.

Selanjutnya atas rekomendasi Majelis Kode Etik (MKE), PNS yang melakukan pelanggaran kode etik selain dikenakan sanksi moral, dapat dikenakan tindakan administratif sesuai dengan peraturan perundang-undangan. "Tindakan administratif dapat berupa sanksi hukuman disiplin ringan maupun hukuman disiplin berat sesuai dengan pertimbangan Tim Pemeriksa.

Dalam hal PNS yang diduga melakukan pelanggaran kode etik adalah PNS selain Sekretaris Daerah, menurut Menteri PANRB Asman Abnur, pembentukan Majelis Kode Etik dan Tim Pemeriksa dilakukan oleh Pejabat Pembina Kepegawaian Instansi PNS yang bersangkutan.

Adapun dalam hal PNS yang diduga melakukan pelanggaran kode etik adalah Sekretaris Daerah Kabupaten/Kota, pembentukan Majelis Kode Etik dan Tim Pemeriksa dilakukan oleh Gubernur sebagai Wakil Pemerintah. Sedangkan dalam hal PNS yang diduga melakukan pelanggaran kode etik adalah Sekretaris Daerah Provinsi, pembentukan Majelis Kode Etik dan Tim Pemeriksa dilakukan oleh Menteri Dalam Negeri.

Menteri PANRB juga mengingatkan adanya ancaman Hukuman Disiplin Tingkat Sedang berupa:

i) Penundaan kenaikan gaji berkala selama 1 (satu) tahun;

ii) Penundaan kenaikan pangkat selama 1 (satu) tahun; dan iii) penurunan pangkat setingkat lebih rendah selama 1 (satu) tahun:

a. Bagi PNS yang memberikan dukungan kepada calon Kepala Daerah/Wakil Kepala Daerah dengan cara memberikan dukungan dan memberikan surat dukungan disertai fotocopy Kartu Tanda Penduduk atau Surat Keterangan Kartu Tanda Penduduk; 
b. Bagi PNS yang memberikan dukungan kepada calon Kepala Daerah/Wakil Kepala Daerah dengan cara terlibat dalam kegiatan kampanye untuk mendukung calon Kepala Daerah/Wakil Kepala Daerah serta mengadakan kegiatan yang mengarah kepada keberpihakan kepada pasangan calon yang menjadi peserta pemilu sebelum, selama, dan sesudah masa kampanye.

Adapun Hukuman Disiplin Tingkat Berat berupa:

1. Penurunan pangkat setingkat lebih rendah selama 3 (tiga) tahun;

2. Pemindahan dalam rangka penurunan pangkat setingkat lebih rendah;

3. Pembebasan dari jabatan; dan

4. Pemberhentian dengan hormat tidak atas permintaan sendiri sebagai PNS:

a. Bagi PNS yang memberikan dukungan kepada calon Kepala Daerah atau calon Wakil Kepala Daerah, dengan cara menggunakan fasilitas yang terkait dengan jabatan dalam kegiatan kampanye;

b. Membuat keputusan dan/atau tindakan yang menguntungkan atau merugikan salah satu pasangan calon selama masa kampanye.

Penjatuhan hukuman disiplin oleh pejabat yang berwenang menghukum dilaksanakan sesuai dengan tata cara yang telah diatur dalam Peraturan Pemerintah Nomor: 53 tentang Disiplin PNS dan Peraturan Kepala Badan Kepegawaian Negara Nomor: 21 Tahun 2010 tengang Ketentuan Pelaksanaan Peraturan Pemerintah Nomor: 53 Tahun 2010 tentang Disiplin PNS, tulis Menteri PANRB.

Menteri PANRB meminta kepada para Pejabat Pembina Kepegawaian atau Penjabat/Pelaksana Tugas Kepala Daerah dan Penjabat Yang Berwenang pada instansi pemerintah untuk melaksanakan dan mensosialisasikan Surat Menteri PANRB ini dengan sebaik-baiknya.

\section{Kesimpulan}

Netralitas PNS, merupakan solusi untuk menyelesaikan permasalahan tentang keikutsertaan PNS dalam partai politik. Dengan lahirnya Undang-Undang No 15 Tahun 2014 tentang Aparatur Sipil Negara, peraturan ini diharapkan dapat menetralkan pemerintah dan kemudian pemerintah harus mampu merealisasikan peraturan tersebut, 
dengan demikian tujuan netralitas akan dapat tercapai. Penegakan hukum terhadap netralitas PNS, dalam realisasinya mengalami kesulitan, karena Pengaturan mengenai penegakan hukum netralitas pegawai negeri yang diatur dalam Undang-Undang No.43 Tahun 1999 Tentang Pokok-Pokok Kepegawaian, yaitu Pasal 3 dan Penjelasan Umum I angka 6, memberi sanksi bagi PNS yang melanggar peraturan ini diberhentikan dari PNS, Peraturan ini hanya mengatur bagi PNS yang menjadi anggota dan pengurus parpol, sehingga peraturan tersebut belum dapat menyelesaikan setiap pelanggaran tentang netralitas.

\section{DAFTAR PUSTAKA}

Gafar, Afan, 1999. Politik Indonesia Transisi Menuju Demokrasi. Yogyakarta: Pustaka.Pelajar; Hadjon, Philipus M., Perlindungan Hukum dalam Negara Pancasila, Makalah simposium tentang Politik Hak Asasi Manusia dan Pembangunan Hukum, dalam Rangka Dies Natalis XL/Lustrum Universitas Airlangga, Surabaya 3 November 1994;

Hartini, Sri, Setiajeng K dan Tedi S. 2008. Hukum Kepegawaian Indonesia, Jakarta: Sinar Grafika;

Kadarsih, Setiajeng, dan Sri Hartini. 2005. Makalah Netralitas Pegawai Negeri Sipil, Jakarta: Mahkamah Konstitusi;

M.D., Mahfud. 1988. Pergulatan Politik dan Hukum di Indonesia. Yogyakarta: Gema Media

Marbun, S.F.1998. Reformasi Hukum Tata Negara”, Netralitas Pegawai Negeri dalam Kehidupan Politikdi Indonesia. Yogyakarta: Fakultas Hukum Universitas Islam Indonesia;

Muchsan.1982. Hukum Kepegawaian. Jakarta:Bina Aksara;

Pandoyo, Toto. 1981. Ulasan Terhadap Beberapa Ketentuan UUD 1945 dan Perkembangan Kehidupan Demokrasi,Yogyakarta: Liberty; Soewoto, Kebebasan Berserikat dan Berkumpul, Makalah Penataran Hukum Administrasi, diselenggarakan oleh Fakultas Hukum Universitas Airlangga bekerjasama dengan Utrecht Universiteit Belanda, 8-13 Februari 1999;

Wijaya, A.W. 1986. Administrasi kepegawaian Suatu Pengantar. Jakarta: CV. Rajawali. 